\title{
Use of Web 2.0 Technologies in the Teaching/Learning of Business Education in Nigerian Universities
}

\author{
Joshua Sule Mamman \\ Department of Business and Entrepreneurship Education, Kwara State University, Malete. P.M.B 1530, Ilorin, \\ Kwara State, Nigeria
}

\begin{abstract}
This paper assessed the use of web 2.0 technologies in the teaching/learning of business education courses in Nigeria Universities. The paper sought answers to the research question "what are the web 2.0 technologies use by lecturers and students of business education in Nigerian Universities? The study adopted both qualitative and quantitative approaches. The descriptive survey was the design used for the quantitative method while content analysis for the qualitative method. A sample of 38 lecturers and 113 students were used for the survey. A total of 151 copies of the questionnaire were administered altogether, and all copies were retrieved and used for the study. A semi-structured interview was the instrument used to gather the qualitative data. Mean, standard deviation and ranks were used to analyze the quantitative data collected. Independent samples t-test statistic was used to test the null hypothesis at the 0.05 level of significance. The qualitative data were analyzed using two themes. The findings of the study revealed that web 2.0 technologies are not used in the teaching/learning of business education. It was also found that lack of technical expertise and uneasiness with openness and public discourse and interactions are some of the reasons why web tools are not used in teaching and learning. Based on the findings, it was concluded that graduates of business education would not be able to get the required skills and competencies to be capable of operating effectively in the 21 st world of employment. Based on the findings of the study, the study recommends among others that; there is the need for business education teachers and students to be given technical support to help them to divert the use of web 2.0 technologies from entertainment to educational uses.

Keywords: Use, web, tools, teaching, learning, business education, Nigeria, Universities
\end{abstract}

DOI: $10.7176 / \mathrm{JEP} / 10-9-23$

Publication date:March $31^{\text {st }} 2019$

\section{Introduction}

The widespread usage of technology is shifting the way we work, play, learn and communicate, even the way we carry out away our regular day-to-day activities. In higher education, technology has induced a striking impact on teaching and learning. Higher educational institutions are well-positioned to take advantage of rapid changes in the field of education and business education in particular. Most importantly, among these technologies, the webbased technologies are at the forefront now and have grabbed the attention of educators. This situation is because these web-based technologies in education offer new opportunities for teachers and students. In particular, the availability of large data sets and real-life cases have the potential to enhance higher education teaching (New Media Consortium, n.d). The proliferation of the Web is now making teachers at all levels of education to reconsider what of teaching, learning, and schooling are. It has been argued that the Web can remove the physical boundaries of classrooms and time restraints of class schedules, with the implication that teaching and learning can take place even on the go. Traditional lectures and demonstrations, according to Edda (2012) can become Web-based multimedia learning experiences for students. Learning resources of universities can be augmented by learning resources of the world via the Web (Conole, 2010). Moreover, the Web can help us re-focus our institutions from teaching to learning, from teacher to student and the students made responsible for their learning. This will go a long way making the students active learners instead of passive listeners in the classroom.

\section{Literature Review}

Web. 2.0 is no longer a new term. It has been there for long. The term was originally coined by O'Reilly in 2005 and is used to refer to the current interactive web-based technologies which give the users the opportunity to make/create information themselves and are differently named as the social web, user-generated web, read-write web, interactive web and so on. In recent years, there has been an explosion of Web 2.0 services and the services themselves evolve rapidly in anticipation of users' demands. Many services have similar functionality which can lead to a baffling level of choice for educators; helpfully there are some guides to the best tools for learning (Strawbridge, 2010). According to Tyagi (2012), web 2.0 described the changing trends in the use of World Wide Web technology and Web design that aim to enhance creativity, communications, secure information sharing, collaboration and functionality of the Web. This paper used the term Web 2.0 quite intentionally to encompass the 
full range of interactive and collaborative web-based technologies and services which have educational value. The application of these tools to the teaching of business education will of great benefit to students and teachers alike. Business Education according to Ubulom (2003) is an aspect of the educational programme which prepares students for careers in business. It is the education that is needed to enlighten people about business, education needed to train people to conduct their personal affairs in order to be productive citizens of society. Some schools of thought believed that business education is a programme of study to produce teachers for secondary and postsecondary schools (Obi, 2012). However, from the foregoing, this paper shares the same view with the Ubulom (2003).

Teachers at all levels of education especially at the university level are always encouraged to look for innovative ways for their students to learn with the use of social media or Web 2.0 tools. Many pedagogical rationales have been advanced to support this change in learning activities. Web 2.0 tools provide a wide range of opportunities for incorporation into higher education activities. These tools can doubtlessly change higher education by helping in the preparation of lesson and actual presentations, assessment of the progress made by the learners, time management, planning the timetable and the calendar of activities, developing projects in collaboration, digital storytelling and students' eportfolios (Conole, 2010). This implied that there are three paradigm shifts: "a shift from a focus on information to communication, a shift from a passive to more interactive engagement, and a shift from a focus on individual learners to more socially situated learning" (Conole, 2010). The areas which web 2.0 might promote new ways of learning include inquiry-based and exploratory learning; new forms of communication and collaboration; new forms of creativity, co-creation, and production; and richer contextualization of learning (Conole and Alevizou, 2010). These tools are very attractive to teaching/learning because learners cannot be passive in these set of technologies in which the learner contributes rather than passively consuming content (as with television). They are also generally easy to apply and affordable (Strawbridge, 2010).

Today's students entering universities and colleges use Web 2.0 applications like wikis, blogs, RSS, podcasting and social networking in their daily lives (Lenhart \& Madden 2005, 2007). Researchers believe that Web 2.0 technologies should be integrated into higher education because today's learners expect to learn with new technologies and for the fact higher education should prepare students for the workplace of the future (Alexander 2006, Prensky 2001, Roberts, Foehr \& Rideout 2005, Strom \& Strom 2007). Researchers have identified several benefits of Web 2.0 technologies to learners in higher education (Alexander 2006, Elgort, Smith \& Toland 2008, Lamb 2004). Multiple studies have focused on one tool, for example, blogs, within a certain discipline. Ellison and Wu (2008), Farmer, Yue and Brooks (2008), Hall and Davison (2007), Williams and Jacobs (2004) and Xie, Ke and Sharma (2008) reported that blogs encourage students to read and provide peer feedback and enhance reflection and higher-order learning skills. Wikis have been found to not only improve students' writing skills but engage students and facilitate collaborative learning in various disciplines (Luce-Kapler 2007; Parker \& Chao, 2007).

The different types of web 2.0 tools available for teaching/learning according to Dhamdhere, (2012) include the following among others:

Learning Management System: Moodle (Course management system) is a Course Management System (CMS), and known as a Learning Management System (LMS) or a Virtual Learning Environment (VLE). These systems are used for creating and deliver training/education through an organized delivery system.

Blackboard (Course Management System): This platform helps to engage more students in exciting new ways, reaching the students on the level with which they desire with the use of their devices and connecting more effectively, keeping them updated, involved by way of effective collaboration.

Mashups: This platform is used to create and integrate information in a very active and user-friendly interface. Files/Information Sharing: The tools in this platform include: drop.io, myfiles.bgsu.edu, furl.net, del.icio.us, Scribd (Document sharing tool) among others.

RSS: This platform allows users to seek out, updates to contents of RSS enabled websites, blogs, podcasts without having to go and visit the site, but information from the site is collected within a 'feed' and 'piped' to users in a process known as syndication.

Wikis: A webpage or a set of web pages can easily be edited by anyone who is allowed to access. It is a collaborative tool which helps in the production of group work, hyperlinking for linking pages. Library wiki as a service can enable social interaction among librarians and patrons, essentially moving the study group room online.

Podcasting: Podcasts are usually included within the Web 2.0 galaxy as another example of user-generated content. Within academic publishing, podcasts are becoming an increasingly common adjunct to online journals and are reported to be very popular. 
Discussion forum/Internet forum: This is an online discussion site where professionals, readers, and others can effectively hold conversations in the form of posted messages. This site is different from chat rooms in that messages are at least temporarily archived. Also, depending on the access level of a user or the forum set-up, a posted message might need to be approved by a moderator before it becomes visible. e.g., mlosc google group, linked in groups, among others.

Flicker (Photos): This is a picture database and an experimental information architecture algorithm that can help the students to find images not by metadata, but by the data itself. Users can search for images by sketching images themselves. It has the features of share, comment, add notes to photos and images which can be used in the classroom/environment.

Video Sharing: One of the video sharing platforms is YouTube which is a video sharing website where users can upload, view and share video clips. Google Video is another tool. Tokbox is used for video chat and video message amongst the study group.

Social Networking: Facebook is a social utility that connects people with friends and others who work, study and live around them. Linked In is a professional social network gives the learner the keys to controlling their online identity and connects them to their trusted contacts and helps the learner exchange knowledge, ideas, and opportunities with a broader network of professionals/users. My space, Twitter, Ning, myspace also shares you with others. For classroom announcements, creating classroom community and learning both inside and outside classroom these tools are used. Classroom 2.0 is a social networking site for collaborative technologies in education.

Slideshare (Presentation sharing): This platform enables users to upload slides to share with others, rate, and comment on the slideshows of others.

Blogs: This is a simple web page consisting of information or links called posts. This platform allows the user to add comments. Communication process through the posting is what is called blogging. Edublog which referred to as Educational Blogging allows users to create and manage student, teacher and library blogs, quickly customize designs and include videos, photos, and podcasts.

Collaborative Authoring: This is also known as collaborative note-taking. In e-learning environment for peer review work, group projects/documents, track changes, collaborative note-taking following tools are used Google Doc, Wikipedia, pbwiki, Wikispaces, stu.dicio.us, among others (Dhamdhere, 2012).

These technologies have come to stay and have found their ways in our everyday life. They are available to make the way we conduct our activities easier, especially teaching and learning. Today's university students are always using web 2.0 technologies. Arguably, the $21^{\text {st }}$-century students have their lives soaked in these technologies, which implied that they are always using them almost all the time. The implication for teachers here is that, if today's students are taught with these technologies, a better result may be gotten. This situation is the reason why this study is conducted to assess the use of web 2.0 technologies in teaching and learning business education in Nigeria universities. The present study is different from previous surveys in several aspects. This paper looks at web 2.0 tools together with teaching/learning and Business Education as the subject matter. It is also asserted that very little has been written about web 2.0 technologies and no or little literature on web 2.0 technologies is available in Nigeria. The researcher, therefore, believes that this study contributes to the existing research literature and at the same time provides teachers, students, curriculum planners University communities and other stakeholders relevant information on the use of web 2.0 tools in teaching and learning. The study sought answers to the following questions:

1. What are the web 2.0 tools used by lecturers of Business Education in Nigeria Universities as perceived by teachers and students?

2. What are the purposes for using Web 2.0 tools by lecturers and students in Nigeria universities?

3. What could be the reasons why web 2.0 tools might not be used for teaching and learning by lecturers and students of business education in Nigeria universities?

The study also tested the following hypothesis:

$\mathrm{H}_{1} \quad$ There is no significant difference between the mean responses of lecturers and students regarding the use of web 2.0 technologies in the teaching and learning of Business Education in Nigerian Universities.

\section{Methodology}

The study used both quantitative and qualitative methods. The descriptive survey research design was used for the quantitative aspect of the study. The population of the study comprised 234 lecturers and 567 students from four Nigerian Universities that offer Business Education (Ahmadu Bello University, Zaria, Kwara State University, 
Malete, Tai Solarin University of Education, Ijagun and Ekiti State University, Ado Ekiti. The researcher believes that the lecturers and students of the Universities are in a better position to know the types of web technologies that are in use in Business Education programme of the Universities. The sampling procedure adopted for the study was proportionate stratified random sampling technique. The lecturers and students are the identified strata. A sample of $30 \%$ of each stratum totaling 38 and 113 of lecturers and students respectively, were selected for the study. This selection was in line with Uzuagulu (1998) who stated that when the population of the study is in a few hundred, the researcher should select $30 \%$ as the sample.

A structured questionnaire tagged Use of Web 2.0 in Business Education (UWBE) designed by the researcher with a split-half reliability coefficient of 0.78 was used to gather the quantitative data for the study. The questionnaire was made up of a total of 24 carefully designed items after an extensive review of the literature. The items are placed on a four-point rating scale of Highly Used (MU), Fairly Used (FU) Not Used (NU), Never Heard Of (NHO) for research question one and Strongly Agreed (SA), Agreed (A), Disagreed (D) and Strongly Disagreed (SD) for research question two. The scales were scored as Highly Used $3.10-4.0$, Fairly Used $2.50-3.09$, Not Used, $1.25-2.49$ and Not Heard Of $0-1.24$. One hundred and fifty-one copies of the questionnaire were administered and collected. The hypothesis was tested using independent t-test statistic at 0.05 level of significance. For the qualitative aspect of the study, five lecturers and 15 students were used as the sample.

A semi-structured interview was conducted to gather qualitative data. The interview guide was designed by the researcher and made up of just one question. The open-ended question was meant to probe into the reasons why lecturers and students that are not using for teaching and learning web 2.0 tools do so. The interviews were conducted at the point of retrieving the copies of the questionnaire administered. This was to make sure that the participants to be interviewed indicated that they are not using web 2.0 tools for teaching and learning. English Language was the medium of communication for the interview because all participants were fluent in English language speaking. Ethical considerations such as informed consent, voluntary participation, and confidentiality were considered. The data was analyzed using content analysis where two emerging themes on the reasons why lecturers and students are not using web tools for teaching and learning were developed.

\section{Results and Discussion of Findings}

Research Question One: What are the web 2.0 tools used by lecturers and students of Business Education in Nigeria Universities?

Table 1. Mean, Standard and Rank of the web 2.0 tools used Business Education lecturers and students in Nigeria Universities $\quad \mathrm{N}=151$

\begin{tabular}{clcccc}
\hline S/N & Web 2.0 Applications & $\bar{X}$ & SD & Remark & Ranks \\
\hline 1 & Wikis & 1.5 & 0.78 & Not Used & $10^{\text {th }}$ \\
2 & Blogs & 1.53 & 0.62 & Not Used & $9^{\text {th }}$ \\
3 & Imo & 2.83 & 0.53 & Fairly Used & $5^{\text {th }}$ \\
4 & Video Sharing & 1.73 & 0.44 & Not Used & $6^{\text {th }}$ \\
5 & Moodle & 1.66 & 0.47 & Not Used & $7^{\text {th }}$ \\
6 & Mushups & 1.23 & 0.71 & Not Heard Of & $11^{\text {th }}$ \\
7 & Facebook & 3.64 & 0.44 & Mostly Used & $1^{\text {st }}$ \\
8 & Calendaring & 1.62 & 0.58 & Not Heard Of & $8^{\text {th }}$ \\
9 & Collaborative suites & 1.15 & 0.48 & Not Heard Of & $1^{\text {st }}$ \\
10 & YouTube & 3.10 & 0.49 & Mostly Used & $4^{\text {th }}$ \\
11 & WhatsApp & 3.29 & 0.49 & Mostly Used & $2^{\text {nd }}$ \\
12 & PowerPoint & 3.11 & 0.38 & Mostly Used & $3^{\text {rd }}$ \\
Aggregate Mean and SD & $\mathbf{2 . 2 0}$ & $\mathbf{0 . 5 3}$ & Not Used & \\
\hline
\end{tabular}

$\mathrm{N}=$ Number of Respondents, $\overline{\mathrm{X}}=$ Mean, $\mathrm{SD}=$ Standard Deviation

Table 1 reveals the responses of lecturers and students on the web 2.0 technologies they use. It is clear from the table that only Facebook $($ mean $=3.64)$, WhatsApp $($ mean $=3.29)$, PowerPoint $($ mean $=3.11)$ and YouTube $($ mean $=3.10)$ are the most used web.2.0 tools by lecturer and students of business education. Imo $($ mean $=2.83)$ is the only fairly used web 2.0 tool. While Video Sharing $($ mean $=1.73)$, Moodle $(\operatorname{mean}=1.66)$, Blogs $(\operatorname{mean}=1.53)$ and Wikis (mean $=1.50)$ are not used by lecturers and students. The respondents indicated that they have not heard of Collaborative Suites (mean $=1.15)$, Calendaring $($ mean $=1.62)$ and Mushups $($ mean $=1.23)$. Summarily, the aggregate mean and standard deviation of 2.20 and 0.53 respectively, attested to the fact that business education 
lecturers and students do not use web 2.0 applications. The standard deviation of 0.53 showed a very low variability of the perceptions of both lecturers and students.

Research Question Two: What are the purposes of using Web 2.0 tools in Nigeria Universities as perceived by lecturers and students?

Table 2. Mean, Standard Deviation and Ranks of the purposes of using web 2.0 tools in Nigeria Universities

\begin{tabular}{clcccc}
\hline S/N & Item Statement & $\overline{\mathrm{X}}$ & SD & Remark & Ranks \\
\hline 1 & Web-based teaching and learning. & 1.34 & 0.47 & Disagreed & $9^{\text {th }}$ \\
2 & Interactive learning features. & 1.59 & 0.49 & Disagreed & $6^{\text {th }}$ \\
3 & To up to date on the related topic of interest. & 1.52 & 0.50 & Disagreed & $7^{\text {th }}$ \\
4 & Online submission of papers. & 1.68 & 0.47 & Disagreed & $3^{\text {rd }}$ \\
5 & Personalized Web services. & 1.60 & 0.49 & Disagreed & $5^{\text {th }}$ \\
6 & Self-publishing on the Web. & 1.62 & 0.49 & Disagreed & $4^{\text {th }}$ \\
7 & Professional communication with others. & 1.46 & 0.50 & Disagreed & $8^{\text {th }}$ \\
8 & Entertainment. & 3.21 & 0.38 & Agreed & $1^{\text {st }}$ \\
9 & For research purposes. & 1.34 & 0.47 & Disagreed & $9^{\text {th }}$ \\
10 & Never use web 2.0 technologies. & 2.67 & 0.43 & Agreed & $2^{\text {nd }}$ \\
Aggregate Mean and Standard Deviation & $\mathbf{1 . 8 0}$ & $\mathbf{0 . 4 7}$ & Disagreed & \\
\hline
\end{tabular}

$\mathrm{N}=$ Number of Respondents, $\overline{\mathrm{X}}=$ Mean, $\mathrm{SD}=$ Standard Deviation

Table 2 reveals that the respondents disagreed with almost all the construct in the table except for items 8 and 10 which they agreed. This is because the two items ( 8 and 10) had mean scores of 3.21 and 2.67 respectively which were above the fixed decision value of 2.50. This indicated that lecturers and students that use web 2.0 technologies use them for entertainment while some of them agreed that they have not heard of web 2.0 technologies. The standard deviation scores showed that the variability in the responses of the respondents was low. The average mean score showed that respondents disagreed that they use web 2.0 for teaching-learning of Business Education.

Research Question three: What could be the reasons why web 2.0 tools might not be used for teaching and learning by lecturers and students of business education in Nigeria universities?

4.1 Technical difficulties

This theme described the participants' perception of the technology related issues why web.2.0 tools are used in teaching and learning. The participants stated that the chief among the reasons why web 2.0 tools are not used in teaching and learning is because they lack the expertise to operate the technologies. Some of the participants said that they do not know how to create groups in the WhatsApp, Facebook and Imo platforms. Some of the participants, especially the teacher participants stated uneasiness when operating web 2.0 tools as the reason for not utilizing them for teaching. Technical difficulties related to students' lack of awareness of new web tools, glitches due to the in-progress nature of many Web 2.0 tools were mentioned by the participants as the reasons for not using web 2.0 tools.

4.2 Confidentiality and timing issues

This theme described issues related to the security of the content and planning time in using web tools for teaching and learning. Some of the participants reported uneasiness with openness and public discourse and interactions. The participants seem to express fears on the security of the post and how the conversation could be controlled during the teaching and learning process. More than 50\% of the participants said that planning to use web 2.0 tools for teaching will waste much time. They used words such as boring, excessively timing wasting, complicated, unreliable, uncontrollable, and not practicable to describe the usage of web 2.0 tools for teaching and learning.

$\mathrm{H}_{1}$ : There is no significant difference between the mean responses of lecturers and students regarding the web 2.0 tools mostly used by lecturers and students in the teaching and learning of Business Education in Nigeria Universities. 
Table 3. Summary of independent t-test result of the mean responses of lecturers and students regarding the Web 2.0 tools used in the teaching/learning of Business Education

\begin{tabular}{lllllll}
\hline Groups & $\mathbf{N}$ & $\overline{\mathrm{X}}$ & SD & t-cal & p-value & Decision \\
\hline Lecturers & 38 & 1.73 & 0.51 & & & \\
Students & 113 & 1.81 & 0.48 & 0.47 & 0.073 & NS$^{*}$ \\
\hline
\end{tabular}

$\mathrm{N}=$ Number of respondents, $\overline{\mathrm{X}}=$ Mean, $\mathrm{SD}=$ Standard Deviation, $\mathrm{NS}=$ Not Significant, $\mathrm{P}>0.05$

The result in Table 3 reveals that the t-calculated of 0.47 with the observed p-value of 0.073 which is higher than the fixed p-value of 0.05 . This indicated that the null hypothesis which states that there is no significant difference between the mean responses of lecturers and students regarding the web 2.0 tools used by lecturers and students in the teaching and learning of Business Education in Nigeria Universities was, therefore, not rejected $\left(\mathrm{t}_{149}=0.47\right.$, $\mathrm{P}=0.073$ ). This implied that teachers and students agreed that the construct listed in Table 1 are not used in the teaching/learning of Business Education.

\section{Discussion of Major Findings}

This study determined the perception of lecturers and students of the use of web 2.0 technologies in the teaching and learning of business education courses in Nigerian Universities. The study found that Facebook, WhatsApp, YouTube are the most used web 2.0 technologies by Business Education lecturers and students. This finding supports the earlier finding of Tyagi (2012) who found that Facebook is at the forefront of web tools used in these days. These findings imply that these web tools have come to stay and their usage would continue to increase. The study also found that the respondents are not heard of three out of 12 web tools used in this study. One of the reasons why web 2.0 tools are not used may because they are recent and most lecturers and students are not aware of the technologies. This finding goes in line with Kelly (2008) who opined that the newness has resulted into fragmented adoption and implementation of these technologies in higher education institutions due to the lack of institutional policies and inadequate knowledge and skills on web 2.0 which have contributed to lack of clear framework on the effective use of these technologies pedagogically or for support. There is no surprise when Grosseck (2009) opined that although there is a consensus on the positive aspects of Web 2.0 in teaching, there is still ignorance of educators as far as its adoption is concerned.

Contrary to this, Laronde (2010) found that faculty members having achieved mastery over technology; educators use it effortlessly as a tool to accomplish a variety of instructional and management goals. Also, in support of this finding, Yuen, Yaoyuneyong, \& Yuen (2011) found that social networking sites were the Web 2.0 technology most commonly used by teachers, followed by social video tools. They found that most teachers did not utilize other Web 2.0 services (blogs, collaborative writing tools, podcasts, social bookmarking or tagging tools, social photo tools, thinking tools, virtual worlds, or wikis) which similar the finding of this study. Buttressing this finding, Edda, (2012) stated that web 2.0 is very new and that it has only been around in anything like its present form for about three years, yet it is already having an impact on higher education. In support of this, Christopher, Pritchett, Pritchett, \& Wohleb (2012) found that social networking and video sharing are the web 2.0 application most often used, though the percentage usage was not encouraging. No wonder, Sawant (2012) found that many faculty members reported that they never use any web 2.0 technologies because they have not heard about them talk more about using them.

The study also found that among the lecturers and students that use web 2.0 technologies use them for entertainment purposes. They are probably unaware of their benefits in application to teaching and learning. This finding coincides with Conole, (2010) who observed that students use web 2.0 technologies, but they do not know to use them to benefit themselves. They use only for entertainment and fun such as for chatting, pinging, poking unnecessary and trivial issues, among others. Also, supporting this finding, Crook et al. (2008) reported that more than a third $(37.4 \%)$ of teachers believe that adopting Web 2.0 resources in the classroom would be timeconsuming for them and teachers find that student use of the internet in class can be hard for them to manage. This implied that web 2.0 applications are not utilized for teaching and learning of Business education in Nigerian Universities. The study also found that respondents agreed that they never use web 2.0, to talk about using them for any purpose. This supports the prior finding by Sawant (2012) who reported that some faculties reported that they never use web 2.0 applications for anything. The study also revealed that lack of technical expertise, planning time, uneasiness with openness and public discourse and interactions are some of the reasons why web tools are not used in teaching and learning. This finding is in line with Mamman and Nwabufo (2013) who found that lack 
of time for planning, adequate technical support and limitation of ICT skills are barriers to the integration of web 2.0 tools. The implication of these findings is that Nigeria University lecturers and students are not updated regarding the integration of technologies in the teaching and learning process.

\section{Conclusion}

This study was an attempt to assess the use of web 2.0 technologies in the teaching and learning of business education in Nigerian Universities. The findings of the study indicated that web 2.0 technologies are not used in the teaching and learning of Business education. Even though traditional teaching and learning paradigms have been shaken by the impact of the integration of new technologies into our educational practices, it looks as if business education appears to be immune against this technological virus that has infected virtually all facets of human life. This implied that the teaching and learning of business education are still carried out under the traditional mode where students are told what to learn, as well as when, where and how. Instead, that knowledge should be actively constructed, and students should be made responsible for their learning. This type of traditional environment does not prepare the learner for the contemporary work world that exists today. Since this is the case, it means that business education is not ready for the $21^{\text {st }}$ century because its graduates would not be able to acquire $21^{\text {st }}$-century skills to meet up with the demands of the present world of work. This means that the graduates would half-baked, the consequences of producing half-baked graduate is better imagined.

\section{Recommendations}

Based on the findings of this study, the following recommendations are made:

1. This study recommends that university management should provide several training courses in web 2.0 technologies which staff should be exposed to in order to respond to the training needs. The respective departments should conduct the training needs assessment.

2. Business education teachers even as digital immigrants should try to stay updated regarding the emerging technologies that can be applied in the teaching/learning process and try to incorporate them into the classroom.

3. There is the need for Business educators to revised and develop Business Education curriculum to deploy ICT application effectively, and they should be specifically designed to fit the emerging Web technologies since they promote and facilitate interactive and collaborative learning.

4. There is a need for university management to provide technical support for staff and students to help them to divert the use of web 2.0 technologies from entertainment to educational uses.

\section{References}

Alexander, B. (2006). Web 2.0 a new wave of innovation for teaching and learning. Educause Review. 15, 30-37

Chinnery, G.M. (2006). Emerging technologies - Going to the MALL: Mobile Assisted Language Learning. Language Learning and Technology, 10(1), 9-16.

Christopher G. Pritchett, C.G., Pritchett, C.C \& Wohleb, E.C (2012). Usage, barriers, and training of Web 2.0 technology applications as reported by certified Educators. The Delta Pi Epsilon Journal, 1(2), 98-102.

Conole, G. \& Alevizou, P. (2010). Literature Review: The use of Web 2.0 in higher education. Milton Keynes: The Open University. Retrieved $20^{\text {th }}$ August 2013 from http://www.heacademy.ac.uk/assets/EvidenceNet/Conole_Alevizou_2010.pdf.

Conole, G. (2010). Bridging the gap between policy and practice: A reflective review and looking forward to the future. Journal of e-Learning and Knowledge Society, 6(1), 1327.

Crook, C., Fisher, T., Graber, R., Harrison, C., Lewin, C., Cummings, J.,-- Sharples, M. (2008). Implementing Web 2.0 in secondary schools: Impacts, barriers, and issues. Retrieved on $23^{\text {rd }}$ September 2013 from http://dera.ioe.ac.uk/1478/1/becta_2008_web2useinschools_report.pdf

Dhamdhere, S.N (2012). ICT and web technology-based Innovations in the education sector. Turkish Online Journal of Distance Education-TOJDE 13 (4) 17

Duke University (2006). Duke Digital Initiative. Retrieved on January 4, 2014 from http://www.duke.edu/ddi/ 
Dzulkefli, Z. M. S, Sin, N. M. \& Mohamad, N. (2012) Selection of web 2.0 technologies and teaching practices among lecturers in selected Malaysia higher education institutions. IEEE Colloquium on Humanities, Science \& Engineering Research 3(1) 45-55

Edda, L. (2012). Making learning and Web 2.0 technologies work for higher learning institutions in Africa, Campus-Wide Information Systems, 29(2), 90 - 107

Elgort, I., Smith, A. G. \& Toland, J. (2008). Is wiki an effective platform for group course work? Australasian Journal of Educational Technology, 24(2), 195-210.

Ellison, N. \& Wu, Y. (2008). Blogging in the Classroom: A Preliminary Exploration of Student Attitudes and Impact on Comprehension, Journal of Educational Multimedia $\quad$ and Hypermedia, 17(1), 24.

Farmer, B., Yue, A. \& Brooks, C. (2008). Using blogging for higher order learning in large cohort university teaching: A case study, Australasian Journal of Educational Technology, 24(2), 123

Grosseck, G. (2009). To use or not to use web 2.0 in higher education? Procedia Social and Behavioral Sciences 1(1) 478-482. Retrieved on $23^{\text {rd }}$ January 2014 from www.Sciencedirect.com

Hall, H. \& Davison, B. (2007). Social software as support in hybrid learning environments: the value of the blog as a tool for reflective learning and peer support. Library and Information Science Research, 29(2), 163-187.

Hamilton, M. \& Richardson, J. () Students' use of Web 2.0 tools in higher education: good practice in assessment and academic integrity - what does it take?

Kelly, B., (2008). A review of current and developing international practice in the use of social networking (Web 2.0) in higher education, Retrieved on January 4, 2014, from http://opus.bath.ac.uk/17702/,

Kumar, S. (n.d). Undergraduate perceptions of the usefulness of web 2.0 in higher education: Survey Development. Retrieved from www.swapnak.ufl.edu on 12 August 2013

Lamb, B. (2004). Wide Open Spaces: Wikis, Ready or Not, EDUCAUSE Review, 39(5), 36-48.

Laronde, G.J.A. (2010). A study of information and communication technology integration by faculty teaching in a ubiquitous laptop Bachelor of education program. Unpublished Ph.D. Dissertation, Ontario Institute for Studies in Education; University of Toronto

Lenhart, A. \& Madden, M. (2005). Teen Content Creators and Consumers", Pew Internet \& American Life Project. Retrieved on January 4, 2014, from http://www.pewinternet.org/pdfs/PIP_Teens_Content_Creation.pdf,

Lenhart, A. \& Madden, M. (2007). Teens and Social Networking", Pew Internet \& American Life Project. Retrieved on January 4, 2014, from http://www.pewinternet.org/pdfs/PIP_SNS_Data_Memo_Jan_2007.pdf,

Luce-Kapler, R. (2007) Radical Change and Wikis: Teaching New Literacies”, Journal of Adolescent and Adult Literacy, 51(3), 214-223.

Mamman, J.S., \& Nwabufo, B.N., (2014). Barriers to the integration of web 2.0 technologies in teaching/learning of business education courses in Nigerian Universities. Nigerian Journal of Business Education, 2(1), 28 - 38

Miller, D.B. (2006). Podcasting at the University of Connecticut: Enhancing the Educational Experience. Campus Technology. Retrieved on January $4, \quad 4, \quad$ from http://campustechnology.com/news_article.asp?id=19424\&typeid=156

New Media Consortium, (n.d). The future of higher education: How technology will shape learning. A report from the Economist Intelligence Unit Sponsored by the New Media Consortium

Obi, E. C. (2012). Business Education and the Entrepreneurship Education Agenda: A Synergy for Unemployment Reduction in Nigeria Mediterranean Journal of Social Sciences, 3(15) 
O'Reilly, T, 2005, What Is Web 2.0: Design Patterns and Business Models for the Next Generation of Software, http://www.oreillynet.com/pub/a/oreilly/tim/news/2005/09/30/what-is-web-20.html

Parker, K.R. \& Chao, J.T. (2007). Wiki as a Teaching Tool, Interdisciplinary Journal of Knowledge and Learning Objects, 3.

Prensky, M. (2001, September/October). Digital natives, digital immigrants. On the Horizon, 9(5), 1-6.

Roberts, D.F., Foehr, U.G. \& Rideout, V. (2005). Generation M: Media in the Lives of 8-18 Year-Olds, MenloPark, CA: Kaiser Family Foundation.

Sawant, S. S. (2012). The study of the use of Web 2.0 tools in LIS education in India Library, Hi Tech News, 29(2),

Strawbridge, F., (2010). Is there a case for web 2.0 in higher education? Do the benefits outweigh the risks?, Assignment for Introduction to Digital Environments for Learning.

Strom, R.D. \& Strom, P.S. (2007). New Directions for Teaching, Learning, and Assessment, Netherlands: Springer Verlag.

Tyagi, S. (2012). Adoption of Web 2.0 technology in higher education: A case study of universities in the National Capital Region, India. International Journal of Education and Development using Information and Communication Technology 8(2), 28-43.

Ubulom, W. J. (2003) An Evaluation of Undergraduate Business Education Programme of tertiary institutions in Rivers State. Business Education Journal, 4(1), 5559

Uzuagwulu, B.N. (1998). Practical guide to writing research report in tertiary institutions. Enugu: John Jacob's classic publishers Ltd

Williams, J., \& Chinn, S. (2009). Using web 2.0 to support the active learning experience. Journal of Information Systems Education, 20, 165-174.

Williams, J.B. \& Jacobs, J. (2004). Exploring the use of blogs as learning spaces in the higher education sector, Australasian Journal of Educational Technology, 20(2), 232-247.

Woodward, J. (2007). Podcasts to support workshops in Chemistry, Retrieved on October 2, 2013, from https://breeze.le.ac.uk/lfconimpalajonny/

Xie, Y., Ke, F., \& Sharma, P. (2008). The effect of peer feedback for blogging on college students' reflective learning processes. The Internet and Higher Education, 11(1),1825.

Yuen, S. C. Y., Yaoyuneyong, G., \& Yuen, P. K. (2011). Perceptions, interest, and use: Teachers and web 2.0 tools in education. International Journal of Technology in Teaching and Learning, 7(2), 109-123. 